\title{
Development of Small-Scale CHP Plant with a Wood Powder-Fueled Stirling Engine"
}

\author{
Katsura SATO ${ }^{* *}$, Norio OHIWA ${ }^{* *}$, Akira ISHIKAWA ${ }^{* *}$, Hidetoshi SHIMOJIMA $^{* * *}$, \\ Akio NISHIYAMA $^{* * * *}$ and Yoichi MORIYA ${ }^{* * * * *}$ \\ ${ }^{* *}$ Chubu Electric Power Co., Inc., Electric Power Research \& Development Center, \\ 20-1, Kitasekiyama, Ohdaka-cho, Midori-ku, Nagoya 459-8522, JAPAN \\ E-mail: Satou.Katsura@chuden.co.jp \\ ${ }^{* * *}$ C-Tech Corporation Ltd., Planning Department, \\ 4-45, Sugumo-cho, Mizuho-ku, Nagoya 467-8520, JAPAN

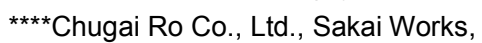 \\ 2-4, Chikko-shinmachi, Nishi-ku, Sakai 592-8331, JAPAN \\ *****First, Inc., \\ 1-7-30, Ashima, Niihama, Ehime 792-0896, JAPAN
}

\begin{abstract}
Small-scale biomass CHP (combined heat and power) plants are in demand for environmental reasons - particularly systems fueled by wood waste, which are simple to operate and require no maintenance while having high thermal efficiency similar to oil-fired units. A 55kWe Stirling engine CHP system, combined with a simplified biomass combustion process that uses pulverized wood powder has been developed to meet these requirements. Wood powder of less than $500 \mu \mathrm{m}$ was mainly used in these tests, and a combustion chamber length of $3 \mathrm{~m}$ was applied. Under these conditions, the air ratio can be reduced to 1.1 without increasing CO emissions by less than $10 \mathrm{ppm}$, and with combustion efficiency of $99.9 \%$. Under the same conditions, NOx emissions are estimated to be less than $120 \mathrm{ppm}$ (on the basis of $6 \% \mathrm{O}_{2}$ ). Wood powder was confirmed to have excellent properties as a fuel for Stirling engines. The $55 \mathrm{kWe}$ Stirling engine performance test was carried out to optimize the operating condition of wood powder burners. The status of Stirling engine operation at a full load with $55 \mathrm{kWe}$ was stable, and start-up and shut -down operations were easy to perform. Operational status was evaluated as being excellent, except for an ash fouling problem in the Stirling engine heater tubes. Ash fouling characteristics were considered in the final stage of the demonstration test. This paper summarizes the wood powder combustion test and Stirling engine performance test. Furthermore, the ash fouling data is shown and the mechanism of ash fouling in heater tubes is discussed.
\end{abstract}

Key words: Ash Fouling, Biomass, Power Generation, Stirling Engine, Wood Powder

\section{Introduction}

The use of biomass will help to establish a sustainable society and conserve the environment, as biomass has the advantages of being a renewable energy source and being neutral in carbon dioxide production. The development and commercial installation of new power technologies utilizing biofuel has progressed rapidly in Japan ${ }^{(1)}$. The use of biomass in large-scale power plants has already begun. The Japanese RPS (Renewable Portfolio Standard) program changed the stance of electric power companies and Independent Power 
Producers, and they are now positively promoting the application of biofuel. Wood biomass co-firing with coal in large-scale pulverized coal (PC) fired power plants is one of the most promising new processes, and many demonstration projects are under way ${ }^{(2)}$. This process uses much of the equipment of existing power plants and is expected to achieve quite high thermal efficiency by utilizing biomass ${ }^{(3)}$.

In mountainous regions, there is a large amount of wood waste from the forestry and timber industries. However, Japanese forestry has atrophied and domestic forest devastation is spreading. Because of this situation, much of the wood waste discharged in mountainous regions is left in the forests of Japan. Furthermore, the rapid rise of oil prices has had an impact on the timber industry and other industries, and has initiated a shift from oil as the primary energy resource to woody waste biomass. Therefore, a distributed power system and small-scale CHP (combined heat and power) plant with biofuel is well suited to industry in Japan's mountainous regions. Many applications for small-scale biomass gasification CHP systems have been developed to meet requests, and many types of biomass gasifier have been proposed and developed in Japan ${ }^{(4)}$. We studied a usable small-scale gasification process and, as a result, we would advise that these systems should be simple to operate and require no maintenance while having high thermal efficiency similar to oil-fired units.

To satisfy these requirements, an external combustion engine such as the Stirling engine should be used in a small-scale power generation system with high thermal efficiency, as it can operate with high temperature flue gas. This means that the biomass energy conversion process applied to the Stirling engine is more flexible and simpler than conventional biomass gasification with a gas engine. On the other hand, a wood powder burner could also be used in a simple combustion system, because wood powder has many advantages as a burner fuel, such as high heating value, high bulk density, small fuel size, good flow ability and so on ${ }^{(5)}$. In 2004 we started to develop a Stirling engine CHP system by applying a simplified biomass combustion process with a pulverized wood powder burner, instead of a gasifier CHP system with gas engine.

The package unit of a $55 \mathrm{kWe}$ Stirling engine using clean gas fuel went on sale in 2005 . We selected this power unit for our CHP system development ${ }^{(6)}$. In addition to this Stirling engine, development of the biofuel Stirling engine has progressed rapidly in Europe and other territories. In Denmark, a wood gas-fueled Stirling engine with $9 \mathrm{kWe}$ power generation has been run successfully; a $35 \mathrm{kWe}$ Stirling engine CHP system assembled with a wood chip fired boiler has been in operation in Austria since 2002; and a $70 \mathrm{kWe}$ Stirling engine pilot plant with eight cylinders, designed according to the above experiments, has also come into operation ${ }^{(7)(8)(9)}$.

We will demonstrate many of our experiences with the wood powder burning technology of co-firing with coal or oil. Fuel properties, combustion and emissions performance, and the risks of bio-fuel are also reported on here ${ }^{(10)(11)}$. Our process was established because the wood powder burner could use $100 \%$ biofuel, and this remained a key issue during our work. Therefore, we first conducted wood powder combustion tests before the Stirling engine unit was installed. According to these test results, the wood powder burner design was optimized for the Stirling engine power system.

At that point, the dummy heater test rig used to simulate an actual Stirling engine was installed at the exit of the combustion chamber, because we had sensed the risk of ash fouling in heater tubes (as earlier reported) ${ }^{(12)}{ }^{(13)}$. As a result of this test, ash fouling in the heater tubes and fins became obvious, and the trial tests for solving or reducing the ash fouling are being carried out with the actual heater tubes and fins of a $55 \mathrm{kWe}$ Stirling engine.

This paper presents combustion test results, details of Stirling engine performance and ash fouling data, and also discusses the mechanism of ash fouling in the heater tubes. 


\section{Experiments and Methodology}

The demonstration plant of the wood powder-fueled $55 \mathrm{kWe}$ Stirling engine power system was completed in March 2006. A general view of the demonstration plant is shown in Fig. 1. The details of this plant and test method are explained subsequently.

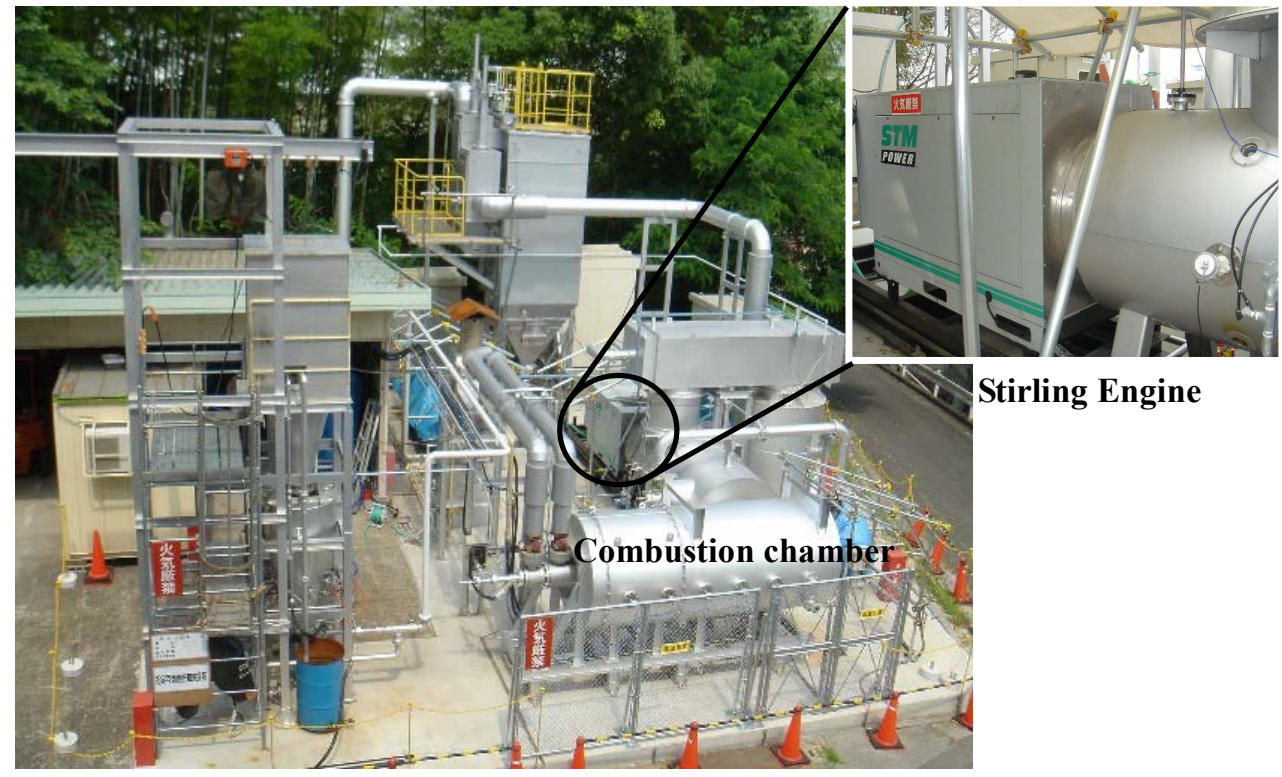

Fig. 1 General view of the demonstration plant

\subsection{Test apparatus}

The test apparatus is shown in Fig. 2. The general specification of the test apparatus is shown in Table 1. A Stirling engine unit of $55 \mathrm{kWe}$ power output was connected to a combustion chamber with a pulverized wood powder burner. A Stirling engine was used with a clean gas fuel type, and some parts of the Stirling engine were modified for wood powder combustion.

Table 1 General specifications

\begin{tabular}{|c|c|}
\hline Item & Specification \\
\hline Generator & $\begin{array}{l}\text { Double acting Stirling engine, } \\
\text { four (4) cylinders }\end{array}$ \\
\hline Combustor & Pulverized wood powder burner \\
\hline Power output & $55 \mathrm{kWe}$ \\
\hline Burning capacity & $400 \mathrm{kWth}$ \\
\hline Fuel feed rate & $\begin{array}{l}\text { Max. } 0.03 \mathrm{~kg} / \mathrm{s} \\
\text { Nor. } 0.02 \mathrm{~kg} / \mathrm{s}\end{array}$ \\
\hline Combustion chamber & $\begin{array}{l}\text { Horizontal chamber, refractory lining, } \\
1.0 \mathrm{~m}-\mathrm{ID} \times 6.0 / 3.0 \mathrm{~m}-\mathrm{L}\end{array}$ \\
\hline Burner type & Dual fueled coaxial type \\
\hline Main fuel & Pulverized wood powder \\
\hline Wood powder size & $\begin{array}{ll}\text { Max.: } & \text { less than } 1.2 \mathrm{~mm} \\
\text { Nor.: } & \text { less than } 0.5 \mathrm{~mm} \\
& \text { (ave. } 0.25 \mathrm{~mm} \text { ) }\end{array}$ \\
\hline Start-up fuel & LPG \\
\hline Draft control & Balanced draft \\
\hline
\end{tabular}




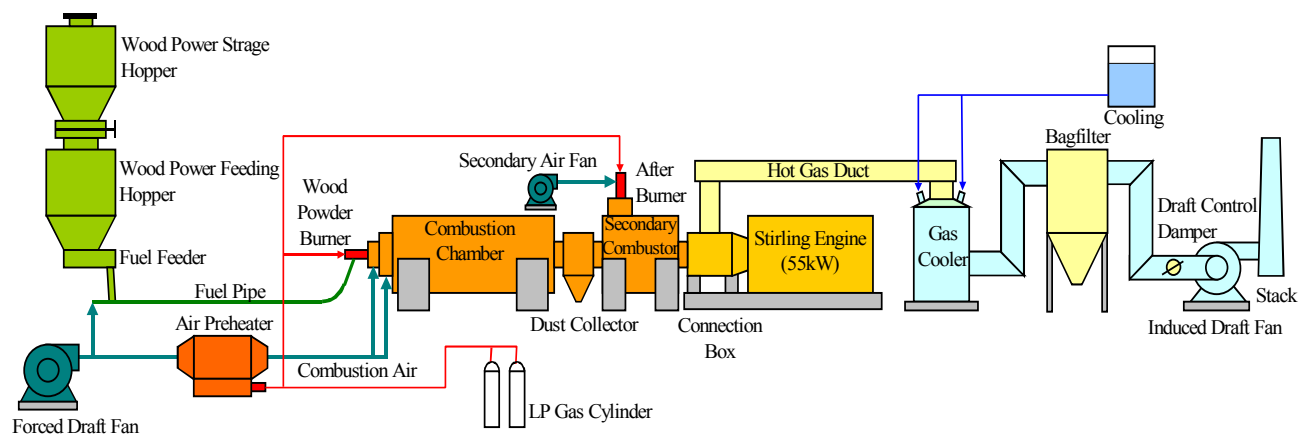

Fig. 2 Test apparatus

Wood powder fuel is transported by air from the fuel hopper, and the fuel feed rate is controlled by the rotating rate of the fuel feeder. Air for combustion and transportation are supplied by a forced draft fan (FDF), and distributed to three portions. There is primary air (PA) for fuel transportation, secondary air (SA) for main combustion air, and tertiary air (TA) for over firing air (OFA). SA is injected into the combustion chamber with a swirl, and TA is fed from outside of the SA without a swirl. PA is not pre-heated, while both SA and TA are preheated up to $573 \mathrm{~K}$ with an air preheater indirectly heated by an LP gas burner.

The wood powder burner is a dual, coaxial type burner, and is modified from a pulverized coal (PC) burner. The two types of burners shown in Fig. 3 were tested. Burner type A is a short flame burner to make high combustion efficiency a priority. Burner type B is a relatively long flame burner to reduce NOx emissions. The two burners were compared for combustion and emissions performance.
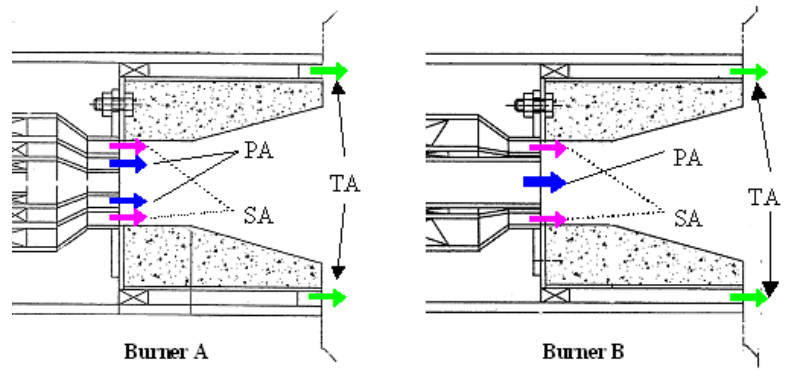

Fig. 3 Wood powder burners

The original combustion chamber was $6.0 \mathrm{~m}$ long horizontally, with refractory lining. After the combustion test with a combustion chamber $6.0 \mathrm{~m}$ in length, the length was reduced to $3.0 \mathrm{~m}$. After evaluation, a chamber length of $3.0 \mathrm{~m}$ was eventually selected for the Stirling engine combustor.

During cold start-up, LP gas is used for the heating process. Burner fuel is switched to wood powder when the chamber temperature reaches $1,073 \mathrm{~K}$. Before the test starts, the combustion chamber exit gas temperature rises to $1,473 \mathrm{~K}$ by wood powder burning. Exhaust gas of the Stirling engine is cooled to less than $473 \mathrm{~K}$ by water spray injection. Dust particles in the flue gas are removed by a bagfilter, and exhausted to the stack by an induced draft fan (IDF). The draft of the combustion chamber is controlled to zero by an IDF with a draft control damper. An online monitoring and logging system is used for process and operation data. During operation, ash and flue gas for analysis are collected at the exit of the combustion chamber. Burner flame patterns are monitored by a video camera and by the operator's own viewing, through the sidewall and rear wall. 


\subsection{Fuel analysis}

Wood powder fuel analysis is shown in Table 2. Wood biomass as a fuel is better than waste fuels or normal coals because of the following properties: high combustion efficiency due to its highly volatile matter, and easily controllable flue gas emissions due to low ash, nitrogen and sulfur. It is also possible to reduce erosion and corrosion risks thanks to low amounts of sulfur, chlorine and ash. However, fouling and slugging troubles in the heating surfaces have to be considered due to high levels of potassium. Ash risks in the Stirling engine heater tubes and fins are discussed hereafter.

To investigate the effect of wood powder size on the current burner temperature profile, a total nine samples were tested. Size distributions of the nine samples (which are named in alphabetical order from A to I) are shown in Fig. 4. Sample A to F were completely burned, and sample $\mathrm{G}$ and $\mathrm{H}$ were burned good. Sample I were not burned so good, more burner modification is required.

Table 2 Wood powder fuel analysis

\begin{tabular}{|c|c|c|c|c|}
\hline \multicolumn{2}{|c|}{ Sample no. } & I & II & III \\
\hline \multicolumn{2}{|c|}{ Particle size } & under $1,200 \mu \mathrm{m}$ & under $500 \mu \mathrm{m}$ & under $250 \mu \mathrm{m}$ \\
\hline HHV & $\mathrm{MJ} / \mathrm{kg}$,dry & 19.12 & 19.04 & 18.94 \\
\hline Moisture & $\%$, wet & 9.62 & 10.20 & 12.30 \\
\hline Volatile matter & $\%$, dry & 81.06 & 81.42 & 81.68 \\
\hline Fixed carbon & $\%$, dry & 18.42 & 18.10 & 17.88 \\
\hline Ash & $\%$, dry & 0.52 & 0.48 & 0.44 \\
\hline $\mathrm{C}$ & $\%$, dry & 52.67 & 52.03 & 52.10 \\
\hline $\mathrm{H}$ & $\%$, dry & 6.09 & 6.03 & 6.15 \\
\hline $\mathrm{O}$ & $\%$, dry & 40.53 & 41.30 & 41.14 \\
\hline $\mathrm{N}$ & $\%$, dry & 0.18 & 0.14 & 0.16 \\
\hline $\mathrm{S}$ & $\mathrm{mg} / \mathrm{kg}$,dry & 140 & 160 & 100 \\
\hline $\mathrm{Cl}$ & $\mathrm{mg} / \mathrm{kg}$,dry & $<50$ & $<50$ & $<50$ \\
\hline $\mathrm{SiO}_{2}$ & $\%$, in ash & 13.85 & 8.99 & 5.71 \\
\hline $\mathrm{Al}_{2} \mathrm{O}_{3}$ & $\%$, in ash & 3.04 & 2.19 & 1.29 \\
\hline $\mathrm{Fe}_{2} \mathrm{O}_{3}$ & $\%$, in ash & 5.92 & 5.23 & 4.76 \\
\hline $\mathrm{CaO}$ & $\%$, in ash & 39.57 & 37.71 & 39.06 \\
\hline $\mathrm{SO}_{3}$ & $\%$, in ash & 4.14 & 3.49 & 3.10 \\
\hline $\mathrm{P}_{2} \mathrm{O}_{5}$ & $\%$, in ash & 1.99 & 1.99 & 1.69 \\
\hline $\mathrm{Na}_{2} \mathrm{O}$ & $\%$, in ash & 3.74 & 2.75 & 1.89 \\
\hline $\mathrm{K}_{2} \mathrm{O}$ & $\%$, in ash & 14.88 & 26.30 & 31.26 \\
\hline
\end{tabular}

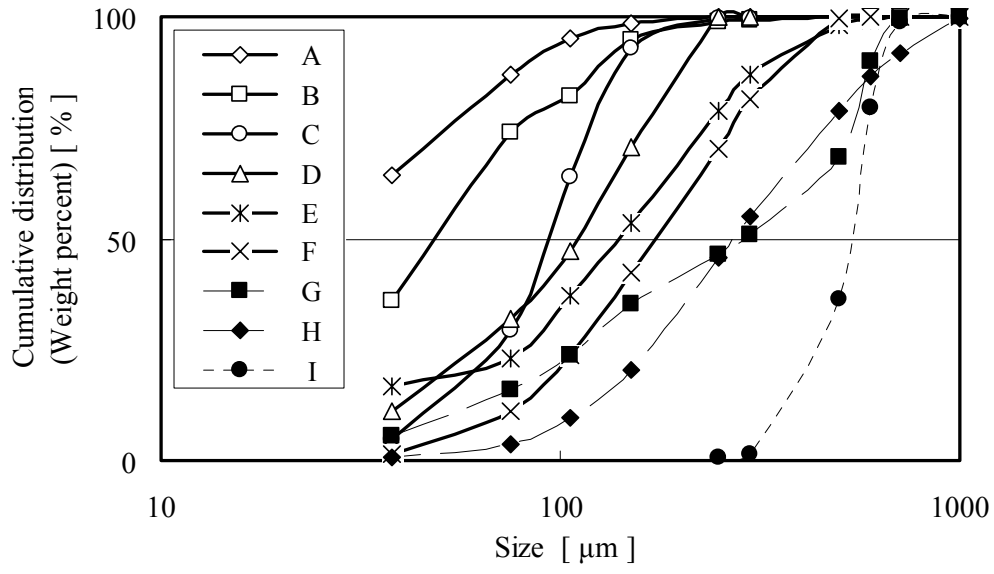

Fig. 4 Size distribution of tested wood powders 


\section{Results and Discussion}

\subsection{Wood powder burner characteristics}

Before beginning power generation operations connected with the Stirling engine, combustion performance of the wood powder burner was tested. The results are described below.

(a) Flame length: We measured the flame length looking from the sidewall peepholes of the combustion chamber (see Fig. 5). We used a particle size equal to that of sample E or F (shown in Fig. 4). It was apparent from observation that the burner flame length was largely dependent on air. In cases of greater burner air ratio with swirling in SA, the flame length is longer. Burner air ratio is $(\mathrm{PA}+\mathrm{SA}) /$ total air. Reduced primary airflow creates a shorter flame. According to these results, the combustion chamber length can be reduced to $3.0 \mathrm{~m}$. The shorter chamber design is expected to obtain better performance for the Stirling engine, because of the higher Stirling engine inlet gas temperature and its smaller heat loss. In commercial design, we estimate that a length of $2.0 \mathrm{~m}$ or less could be used.

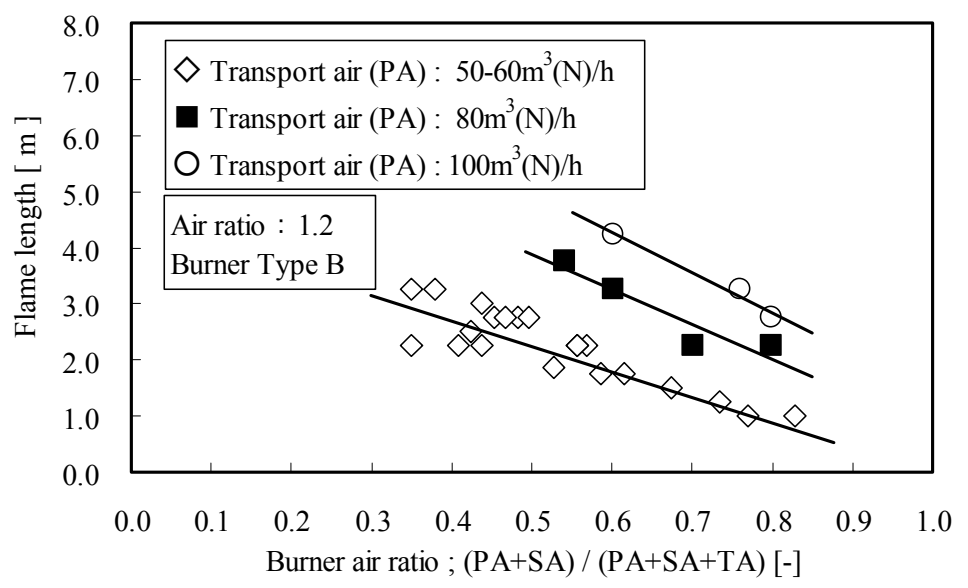

Fig. 5 Measured flame length

(b) Combustion temperature: Fig. 6 shows the combustion chamber outlet gas temperature correlating with combustion air ratio. Higher air ratio reduces gas temperature by the cooling effect of combustion air. As evaluated in section 3.3, a higher air ratio is expected to improve performance of the Stirling engine, while lower gas temperature results in worse performance. The optimization of combustion air ratio is important for commercial plant design. These results are applied to the simulation model, in order to evaluate commercial units.

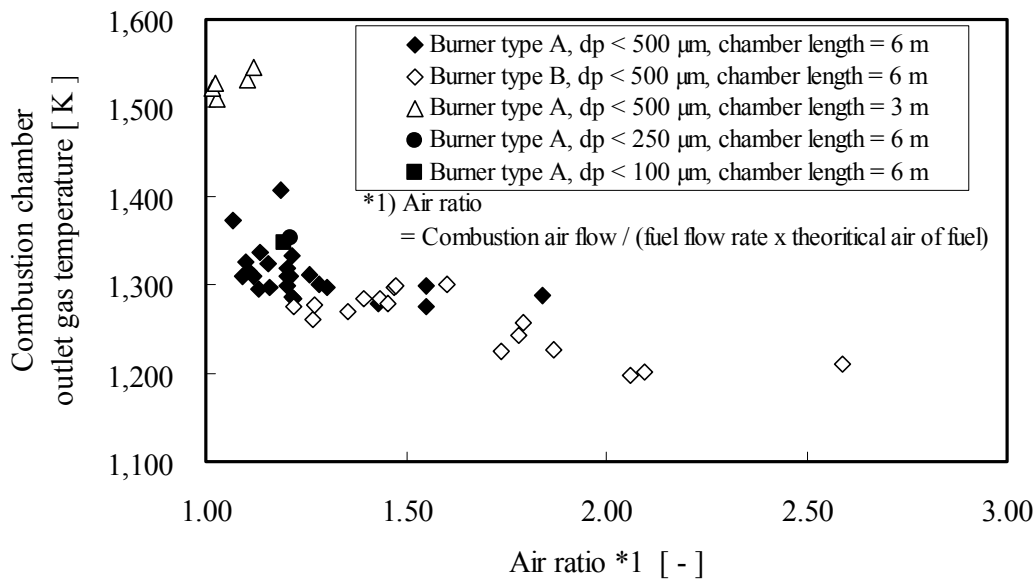

Fig. 6 Combustion chamber gas temperature 
(c) Combustion efficiency and NOx: Fig. 7 shows the combustion efficiency and NOx emissions of wood powder. In cases where the air ratio is between 1.1 and 1.2, combustion efficiencies are greater than $99.9 \%$, and NOx emissions are $120 \mathrm{ppm}$ (on a basis of $6 \% \mathrm{O}_{2}$ ) or less. Both performances are quite excellent when compared with normal coals. Here, combustion efficiencies are calculated with Eq. (1).

$$
\begin{aligned}
& \eta_{C}=\left\{1-\left(G_{u b c} \cdot \alpha \cdot G_{f}+V_{c o} \cdot \beta \cdot G_{f}\right) /\left(G_{f} \cdot L H V\right)\right\} \times 100 \\
& \eta_{C} \quad: \text { combustion efficiency based on lower heating value, } \% \\
& G_{u b c} \quad: \text { unburned carbon content, } \mathrm{kg} / \mathrm{kg} \text {-fuel } \\
& \alpha \quad: 33.9 \mathrm{MJ} / \mathrm{kg}-\mathrm{C} \\
& V_{C O} \quad \text { : combustion chamber exit } \mathrm{CO} \text { content, } \mathrm{kmol} / \mathrm{kg} \text {-fuel } \\
& \beta \quad: 283 \mathrm{MJ} / \mathrm{kmol}-\mathrm{CO} \\
& G_{f} \quad: \text { fuel feed rate, } \mathrm{kg} / \mathrm{s} \\
& \text { LHV : lower heating value of fuel, } \mathrm{MJ} / \mathrm{kg}
\end{aligned}
$$

Unburned carbon in fly ash (UBC) was analyzed by using dust samples captured at the combustion chamber exit, and unburned carbon content $G_{u b c}$ was calculated by Eq. (2).

$$
\begin{aligned}
& G_{u b c}= U B C \times A S H / 10000 \\
& U B C \quad: \text { unburned carbon in fly ash, \% } \\
& A S H \quad: \text { ash content in fuel, \% }
\end{aligned}
$$

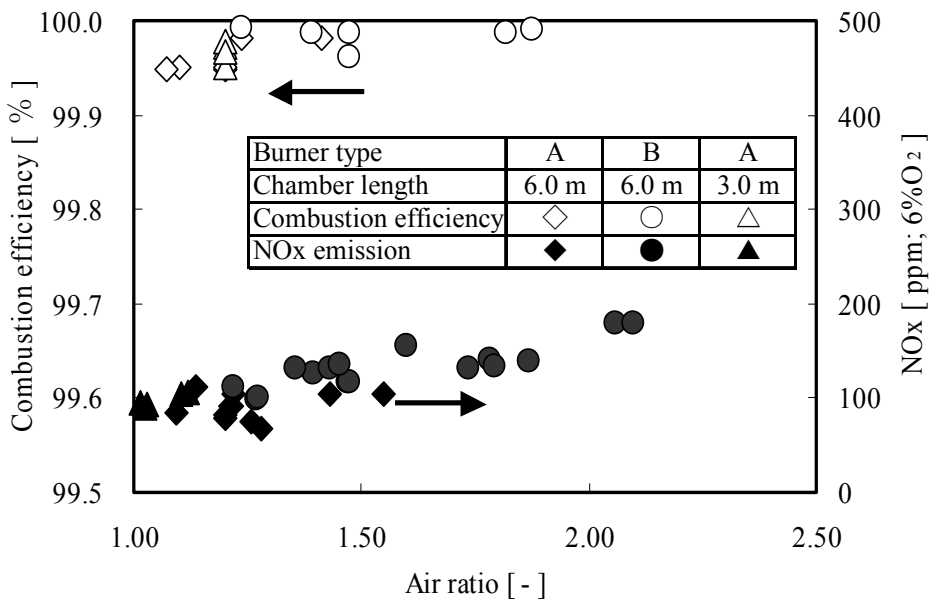

Fig. 7 Combustion efficiency and NOx

\subsection{Stirling engine operation test results}

The Stirling engine was operated with burning wood powder fuel beginning in April 2006. Operation results follow, along with typical data.

(a) Stirling engine performance: Stirling engine power output was measured in various gas flows and gas temperatures with LPG combustion gas. As shown in Fig. 8, Stirling engine power output is closely correlated with gas flow and gas temperature. In cases where the gas temperature is $1,273 \mathrm{~K}$ or lower, a large gas flow rate is needed. That is, the design capacities of the fan system and flue gas treatment system increase. Gas temperature of the Stirling engine is expected to be higher than $1,373 \mathrm{~K}$. The wood powder burner can easily achieve a gas temperature of $1,473 \mathrm{~K}$ or higher, and this is suitable for the Stirling engine combustor.

(b) Stirling engine operation: The start-up and shut down curve of the $55 \mathrm{kWe}$ power plant is shown in Fig. 9. As the Stirling engine inlet gas flow and temperature increase, the Stirling engine power output also increases in quick response. Once the engine operator 
pushes the engine start button, the Stirling engine power output automatically increases according to the inlet gas flow and temperature. The operator does not need to pay any attention to the Stirling Engine when it is being shut down. In commercial plants, we expect fully automated operation and control systems to be established.

\subsection{Discussion regarding ash fouling}

With burning wood powder, pressure losses of heater tubes increase rapidly, as shown in Fig. 10. In cases where the Stirling engine inlet has a higher gas temperature, the increase of pressure losses tends to happen quickly. According to our inspection, this is caused by ash fouling in the heater tubes and fins, as shown in Fig. 11.

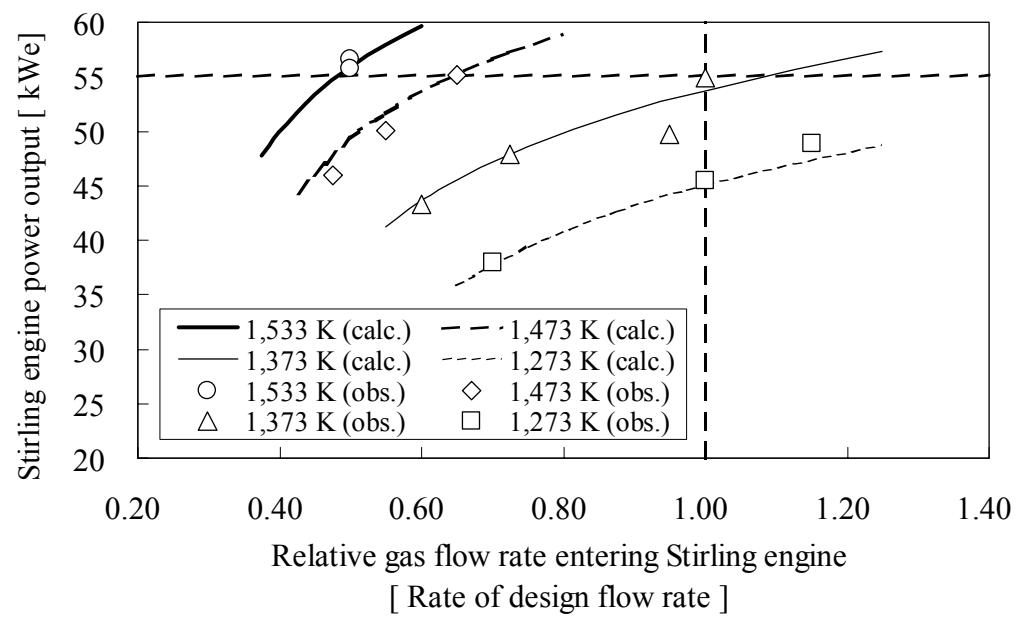

Fig. 8 Stirling engine power output

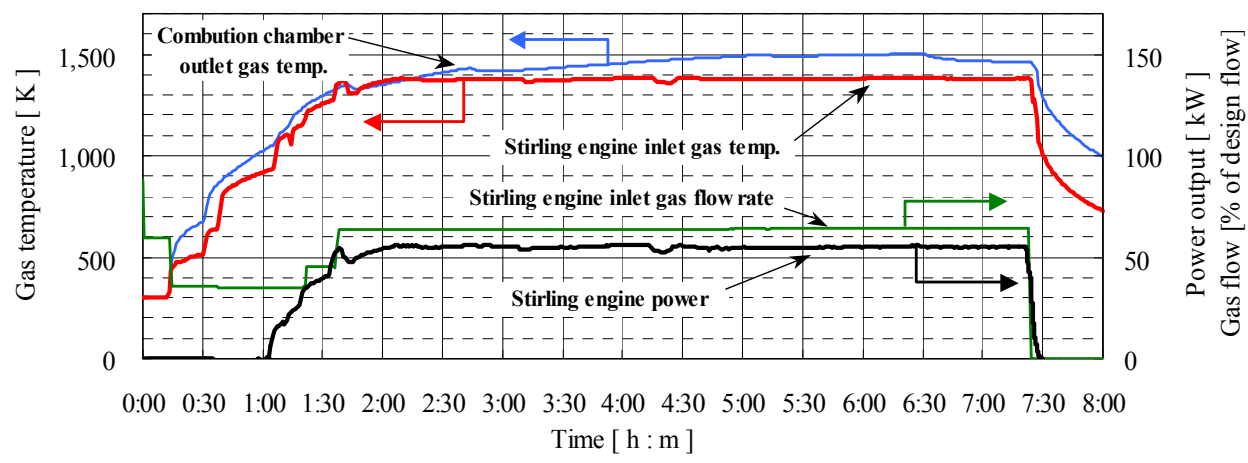

Fig. 9 Start-up and shut-down curve

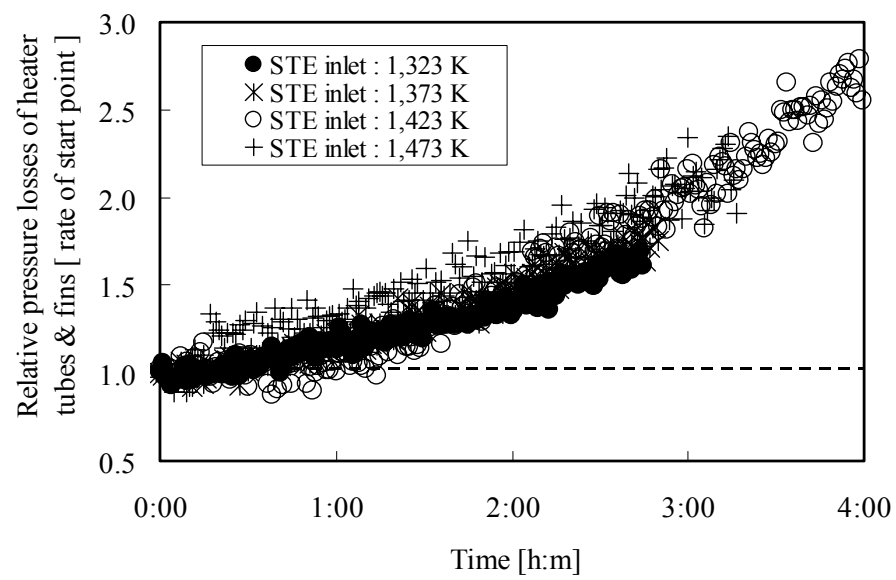

Fig. 10 Operational status after wood burning 
Analysis data of ash components of the heater tube surfaces compared with fuel ash are shown in Fig. 12 and Fig. 13. All of those contain a far greater amount of potassium than fuel ash (that is, potassium accumulates on the tube surfaces).

Furthermore, potassium increases in the higher gas temperature of the burner zone (see Fig.12), and thereby also increases the lower cylinder temperature (see Fig.13). Higher gas temperature and lower cylinder temperature results in the production of a greater amount of potassium vapor in the flue gas entering the Stirling engine. Potassium is generally included in wood ash and is evaporated in the combustion zone, and condensed on the heater tube surfaces. At that time, potassium accumulates other ash particles of $\mathrm{Ca}$, $\mathrm{Si}$, etc., in the flue gas.

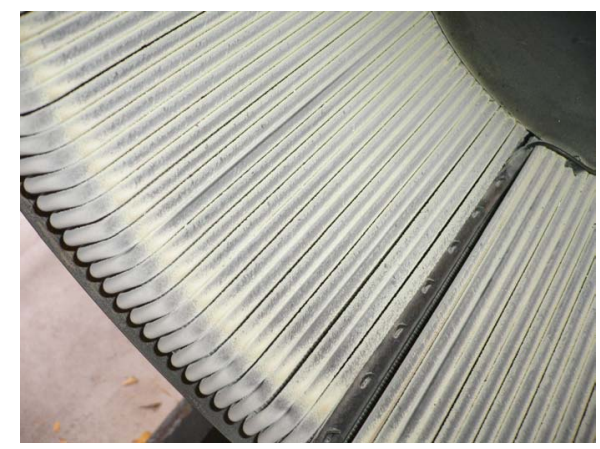

Fig. 11 Ash sticking in heater tubes

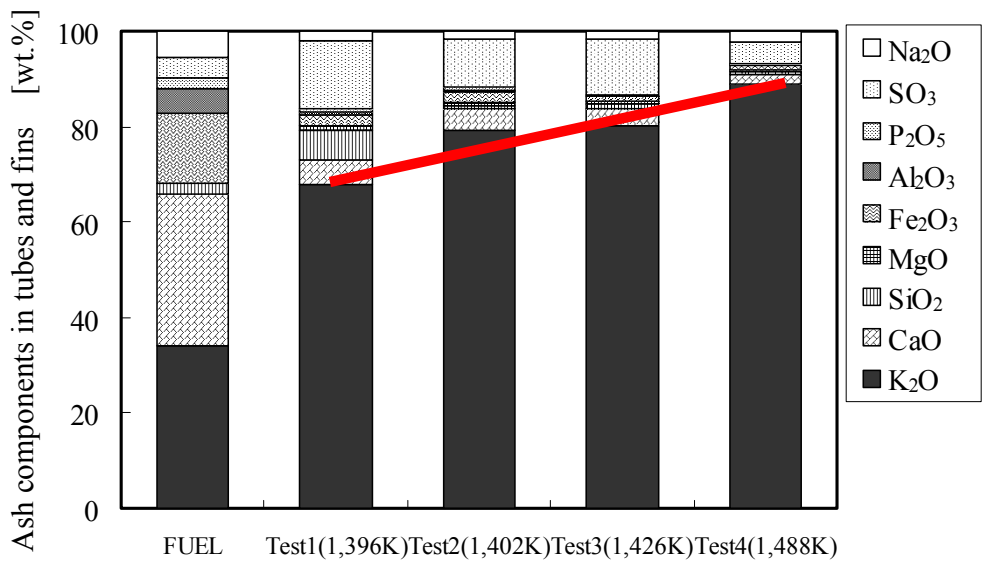

Maximum temp. in burner zone [ $\mathrm{K}$ ]

Fig. 12 Ash components against gas temperature in the burner zone

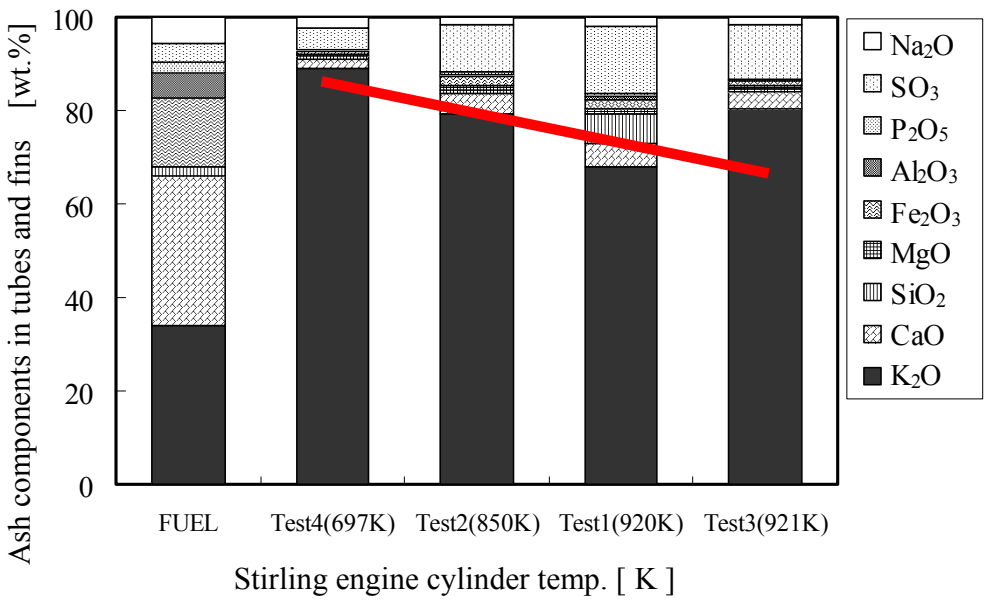

Fig. 13 Ash components against cylinder temperature 
When the temperature of the Stirling heater tube surface is approximately $1,073 \mathrm{~K}$, this temperature is perfectly suitable for condensing potassium $\left(\mathrm{KOH}\right.$ or $\left.\mathrm{K}_{2} \mathrm{SO}_{4}\right){ }^{(14)}$. In the high performance Stirling engine, which requires a high combustion temperature, it is not easy to avoid the above-mentioned ash fouling problem in Stirling engine heater tubes and fins. The combustion temperature and gas temperature entering the Stirling engine are given greater consideration in order to minimize the amount of ash fouling. Additionally, a simplified ash cleaning system shall be developed for commercial plant systems.

\section{Conclusions}

In order to supply a simplified small-scale biomass CHP system, the Stirling engine power system combined with a wood powder burner was developed. Demonstration tests were carried out using a $55 \mathrm{kWe}$ Stirling engine power unit. Test results and conclusions are as follows:

The air ratio could be reduced to 1.1 without increasing $\mathrm{CO}$ emissions of less than 10 ppm and while maintaining combustion efficiency of $99.9 \%$. Under these air ratio conditions, NOx emission was $120 \mathrm{ppm}$ (on a basis of $6 \% \mathrm{O}_{2}$ ) or less.

The Stirling engine power output was defined by inlet gas flow and gas temperatures. The Stirling engine inlet gas temperature was required to be $1,373 \mathrm{~K}$ or higher in order to maintain a power output of $55 \mathrm{kWe}$.

The wood powder-fueled Stirling engine system demonstrated high performance, easy operability and simple maintenance. It could be possible to apply a fully automated operation and control system in commercial systems.

With a high performance Stirling engine system, it was not easy to avoid the problem of ash fouling. Optimizations of combustion temperature and Stirling engine inlet gas temperature are necessary, as is the development of an ash cleaning system.

\section{Acknowledgements}

We wish to acknowledge the support of the New Energy and Industrial Technology Development Organization (NEDO).

\section{References}

(1) Moritsuka H. Survey on Domestic and Foreign Biomass Power Generation Technologies. Journal of the Japan Institute of Energy. 2006; 868-875.

(2) Nakamura T, Nakagawa K. Tanaka M, Suzuki A, Kaneuji T, Kimoto M. Power Generation by Coal \& Biomass Cofiring. Journal of Thermal and Nuclear Power Engineering Society. 2006:10; 839-858.

(3) Nishiyama A, Harigane Y, Kanbara S, Moritomi H. Cost Simulation Study for the Biomass Co-combustion System in Large Scale Power Plant. Proceedings of the International Conference on Coal Science and Technology, Okinawa Convention Center, Ginowan city, Okinawa, Japan. 9-14 October, 2005.

(4) Nishiyama A. Serialization on producing electricity by wood No.4 - Current Topics on the Electric Power Devices for Biomass Gasifier. Quality Journal of Wood Based Energy. 2005; 7:19-22.

(5) Demirbas A. Meydan F. Utilization of Biomass as Alternative Fuel for External Combustion Engines. Energy Sources 2004;26:1219-1226.

(6) Sato K. Ohiwa N. Research and development of Stirling engine power generating system using biomass. Proceedings of the 10th Symposium on Stirling Cycle. Kanagawa University, Yokohama, Japan. 20-21 October, 2006.

(7) Carlsen H. Bovin J K. Test of $9 \mathrm{~kW}$ Stirling engine using biogas as fuel. Proceedings of the 10th International Stirling Engine Conference 2001;278-285. 
(8) Biedermann F. Carlsen H. Schoech M. Obernberger I. Operating Experiences with a Small-scale CHP Pilot Plant based on a $35 \mathrm{kWel} \mathrm{Hermetic} \mathrm{Four} \mathrm{Cylinder} \mathrm{Stirling} \mathrm{Engine}$ for Biomass Fuels. Proceedings of the 11th International Stirling Engine Conference, Rome (Italy). 19-21 November 2003.

(9) Carlsen H. Biedermann F. Bovin J K. Large eight.cylinder Stirling engine for biofuels. Proceedings of the 11th International Stirling Engine Conference, Rome (Italy). 19-21 November, 2003.

(10) Kastanaki E. Vamvuka D. A comparative reactivity and kinetic study on the combustion of coal-biomass char blends. Fuel 2006;85:9,1186-1193.

(11) Pronobis M. The influence of biomass co-combustion on boiler fouling and efficiency. Fuel 2006;85:4:474-480.

(12) Thy P. Lesher C E. Jenkins B M. Grundvig S. Compositional constraints on slag formation and potassium volatilization from rice straw blended wood fuel. Fuel Processing Technology. 2006;87:5: 383-408

(13) Carlsen H, Schöch M, Obernberger I. Development of a hot gas heat exchanger and a cleaning system for a $35 \mathrm{kWel}$ hermetic four cylinder Stirling engine for solid biomass fuels. Proceedings of the 12th International Stirling Engine Conference, Durham, UK. 7-9 September. 2005.

(14) Riedl R. Dahl J. Obernberger I. Narodoslawsky M. Corrosion in fire tube boilers of biomass combustion plants. Proceedings of the China International Corrosion Control Conference'99. Paper No. 90129. (1999.10) 